\title{
Escola de Aprendizes Artífices ou Escola de Aprendizes e Artífices?
}

\section{School of Artificers Apprentices or School of Apprentices and Artificers?}

\author{
Irineu Mario Colombo*
}

\begin{abstract}
RESUMO
O marco inicial de uma política nacional de formação profissional foi a criação de 19 Escolas de Aprendizes Artífices por um Decreto federal em 1909. Após encontrar inúmeros equívocos em dissertações e teses, que apresentavam a origem da rede federal de educação profissional e tecnológica, usando os termos "aprendizes artífices" acrescentando "e", ficando "aprendizes e artífices", apresentou-se o desafio que resultou na pesquisa para este artigo, a fim de tentar entender este uso e apresentar a significação diacrônica, do ponto de vista conceitual, histórico e socioeconômico. Esta pesquisa utilizou a busca quantitativa dos usos dos termos em buscadores informáticos, a partir da qual procedeu-se à análise referenciada em bibliografia relativa aos aspectos históricos, econômicos e sociais, refletidas no uso conjuntural e da significação linguística de cada tempo. Por fim, a reflexão procura traduzir o interesse político, jurídico e social por trás daquela expressão, que se relaciona à estrutura de uma época e revela que o uso adequado do termo, ao preservar sua originalidade, traduz um significado que é dialético, tanto na representação como na base material da sociedade da época.
\end{abstract}

Palavras-chaves: Educação profissional. Escola de Aprendizes Artífices. História da educação. Semântica.

\begin{abstract}
The first landmark event of a national policy about professional formation in Brazil was the foundation of 19 Schools of "Aprendizes Artífices" under a federal decree in 1909. After finding numerous mistakes in dissertations and
\end{abstract}

* Instituto Federal do Paraná. Pinhais, Paraná, Brasil. E-mail: colombo.irineu@gmail.com https://orcid.org/0000-0001-5316-0831 
theses, which presented the origin of the federal network of professional and technological education, using the terms "school of artificers apprentices" adding " $\mathrm{e}$ " between the terms, then becoming "school of apprentices and artificers", had presented the challenge that fostered the research for this article, in order to try to understand this use and present the diachronic significance, from a conceptual, historical and socioeconomic point of view. This research employed a quantitative search of the uses of the terms in computer search engines, from which the analysis was referenced in bibliography related to the historical, economic and social aspects, reflected in the conjunctural use and the linguistic significance about each one. Finally, the reflection seeks to translate the political, legal and social interest of that expression, which is related to the structure of an era and reveals that the proper use of the term, while preserving its originality, translates a meaning that is dialectical, both in representation and on the material basis of the society of that time.

Keywords: Professional education. School of Artificers Apprentices. History of education. Semantics.

\section{Introdução}

A publicação do Decreto Federal número 7.566, em 23 de setembro de 1909, criou as Escolas de Aprendizes Artífices "em cada uma das capitaes dos Estados da República" mantidas pelo "Ministério da Agricultura, Industria e Commercio" para o "ensino profissional primário gratuito" que "procurará formar operários e contra-mestres" (BRASIL, 1909). Em 1910 foram instaladas então 19 Escolas de Aprendizes Artífices. Em torno do significado das palavras que intitulam cada uma das instituições vai girar nosso artigo.

Buscamos embasar teoricamente este trabalho em bibliografia sobre história da educação profissional no Brasil, sobre a questão linguística e nos debruçamos sobre o próprio Decreto e demais normas decorrentes, assim como dicionários da época. Adotamos como método quantificar o uso atual das palavras "aprendizes" e "artífices" nas citações sobre as escolas, para dimensionar e verificar quão significativo era o problema, depois procuramos entender a tendência ao uso da partícula "e" entre as palavras, bem como associar ao significado linguístico e histórico de cada uma, para apontar o anacronismo, ao se acrescentar a partícula "e" ao tratar dos ofícios e das intenções políticas da época.

A análise levou em conta os termos e sua significação em seu tempo histórico, político e econômico, sob a lente histórico-filosófica da relação 
entre trabalho manual e intelectual, visto que as Escolas de Aprendizes Artífices inauguram um sistema nacional, contando com "prédios, currículos e metodologia didática próprios" (CUNHA, 2000b, p. 94), que as distinguia das demais instituições e experiências similares anteriores.

Porém, para situarmos o leitor na conjuntura da época e por uma questão de estímulo didático à leitura, iniciamos apresentando o autor do Decreto: Nilo Peçanha.

No Período Imperial da história brasileira (1822 até 1889), as escolas profissionalizantes eram de caráter assistencial, voltadas para dar ocupação e correção aos mais pobres. Mesmo nas proximidades da Proclamação da República "podemos perceber a presença de escolas profissionalizantes criadas e mantidas pelo Estado, sociedade civil ou igreja, quase sempre com características próprias da filantropia" (MÜLLER, 2010, p. 194).

Inaugurado o período republicano, surgem inúmeras empresas no Brasil, advindas da lenta mudança de capitais do setor agroexportador para a indústria incipiente, bem como há uma mudança sutil nas opções da política educacional para atender a esta demanda.

O Brasil era oficialmente "Estados Unidos do Brasil", em que cada província imperial havia se tornado federação (estado) que estavam unidos na confederação nacional - como cópia dos Estados Unidos da América (EUA). Cada federação elegia seu presidente. O Estado do Rio de Janeiro, capital do Brasil, era governado pelo presidente estadual Nilo Peçanha.

\section{Nilo Peçanha e o Decreto No 7.566, de 23 de Setembro de 1909.}

Nilo Procópio Peçanha nasceu em Campos dos Goytacazes (Rio de Janeiro), em 1867, e faleceu na cidade do Rio de Janeiro, em 1924. Cresceu num Distrito municipal chamado Freguesia de Nossa Senhora da Penha do Morro do Coco. De família pobre, estudou o primário em escola pública em Campos e o secundário em Niterói, enquanto ajudava o pai numa padaria da família.

[...] o Nilo era mulato. Até 1909, quando Nilo Peçanha chega ao Palácio do Catete, o Brasil nunca tinha tido, desde a chegada dos portugueses em 1500, um chefe de estado. Com uma origem e uma cor de pele tão parecida com a maior parte da população. Hoje, há quem considere o Nilo nosso primeiro e único presidente negro. E olha só! Cem anos antes de Barack Obama (PRESIDENTE DA SEMANA, 2018, 1'08' - 1'27'). 
Iniciou seus estudos de Direito na Faculdade de São Paulo, contudo formou-se pela Faculdade do Recife (FERREIRA, 2019, p. 1), retornando à cidade natal para exercer advocacia e jornalismo. Convivendo com as questões sociais do final do Império, sofreu preconceito por ser mestiço ${ }^{1}$. Nesta mesma época passou a apoiar o abolicionismo e a instauração do republicanismo, com um discurso empolgante e, com apenas 20 anos, defendia estas questões a pleno pulmões em praça pública.

Em 1890, foi eleito deputado à Assembleia Nacional Constituinte de 1901 pelo Partido Republicano, iniciando sua vida política. Depois exerceu vários mandatos como deputado estadual até 1903, ano em que foi eleito presidente do Estado do Rio de Janeiro para mandato até 1906.

Em seu último ano de mandato como Presidente do Estado do Rio de Janeiro (sairia para ser vice-presidente da República em 15 de novembro de 1906), Nilo Peçanha criou 4 escolas profissionais: em Campos, Petrópolis, Niterói e Paraíba do Sul (BRASIL, 2008, p. 2). Este ano também é considerado um marco no ensino profissional brasileiro, pois: a) é realizado o Congresso de Instrução, em que um projeto de ensino profissional é apresentado ao Congresso; b) o Senado aumenta a dotação orçamentária para criação de novas escolas pelo governo federal; c) o Presidente da República Afonso Pena defende a criação de institutos técnicos, procede em seguida à reorganização do ensino agrícola e funda escolas Comerciais em São Paulo, Rio de Janeiro e Bahia (MÜLLER, 2010, p. 195; BRASIL, 2008, p. 2).

Na perspectiva teórica da história política,

Não foi mero acidente histórico o fato de o político fluminense Nilo Peçanha se destacar no cenário nacional. Medidas políticoadministrativas quando governador do seu estado natal e a forma como aproveitou os dividendos do relativo sucesso dessa administração, fizeram o político Nilo Peçanha criar uma máquina político-partidária com o intuito de projetá-lo em escala nacional, concretizando as ambições políticas de uma fração minoritária da oligarquia localizada num estado de segunda grandeza frente o domínio das oligarquias mais poderosas, representantes dos estados de São Paulo, Minas Gerais e Rio Grande do Sul (CARVALHO, 2017, p. 104).

1 "Mestiço do Morro do Coco" como era chamado pelos seus adversários, fazendo alusão à sua cor, devida a mistura de etnias, sendo "negro claro" ou "mulato". Por ser mestiço era também ridicularizado na imprensa com anedotas e charges (FERREIRA, 2016, p. 7). 
Em $1^{\circ}$ de março de 1906, Nilo foi eleito Vice-Presidente da República na chapa de Afonso Pena, para mandato entre 1906 e 1909:

[...] foi eleito vice-presidente da república (na época, os vices eram eleitos separadamente), com 272.529 votos contra apenas 618 votos dados a Alfredo Varela. Seus seguidores eram chamados de niilistas. Com a morte de Afonso Pena, em 1909, Nilo Peçanha assume a Presidência da República (FERREIRA, 2016, p. 8).

Torna-se então o sétimo Presidente da República, para governar no biênio 1909 e 1910. Com apenas 3 meses na chefia do executivo nacional, fez publicar um Decreto para a criação de escolas profissionalizantes federais, a exemplo do que havia feito como Presidente de Estado 3 anos antes.

\begin{abstract}
No novo posto, procurou implementar algumas medidas que expressavam sua crença na diversificação da produção. De acordo com essa orientação, criou o Ministério da Agricultura, Indústria e Comércio, cuja meta era modernizar o Brasil através da atualização do setor agrário, tendo como base o conhecimento científico. Ainda com essa perspectiva criou Escolas de Aprendizes Artífices (EAA), dando início ao desenvolvimento do ensino técnico no país (FERREIRA, 2019, p. 4).
\end{abstract}

A Rede Federal de Educação Profissional e Tecnológica atual é composta por 38 Institutos Federais, 2 Centros Federais de Educação Tecnológica (CEFETs), 24 Escolas Técnicas Vinculadas às Universidades Federais, a Universidade Tecnológica Federal do Paraná e o Colégio Pedro II. Esta rede teve início com a assinatura do Decreto $\mathrm{n}^{\circ} 7.566$, que criou 19 escolas profissionais, as Escolas de Aprendizes Artífices, sob a mesma normativa e regramento funcional, iniciado como um sistema federal de educação profissional primária, em 1909.

Segundo Manoel Soares são três as fontes inspiradoras, ou os antecedentes que indicaram os objetivos e a estrutura destas escolas: o Asilo de Meninos Desvalidos, as escolas profissionais do Estado do Rio e o anteprojeto de lei formulado pelo Congresso de Instrução de 1906 (SOARES, 1981, p. 69).

No Asilo de Meninos Desvalidos, inaugurado em 1875, eram ministrados na instrução primária, "álgebra elementar; geometria plana e mecânica aplicada às artes; escultura; música vocal e instrumental”. Também aprendiam os ofícios de 
"tipografia, encadernação, alfaiataria, carpintaria, marcenaria, tornearia, entalhe, funilaria, ferraria, serralheria, correaria e sapataria" (SOARES, 1981, p. 74). O Asilo atendia meninos de 6 a 12 anos sem defeito físico, com expectativa de correção. Havia professores para as aulas teóricas e mestres de ofício para as aulas práticas nas oficinas. Mais tarde passou a se chamar Instituto Profissional.

O Congresso de Instrução, realizado no Rio de Janeiro em 1906, propôs ao governo federal realizar ensino prático nas áreas comercial, industrial e agrícola. Sugeriram criação de institutos disciplinares em cada estado para ensino prático nas três áreas, e, ainda, ensino doméstico para moças, internato para menores viciosos e desamparados, e curso de aprendizagem de ofícios nos quartéis. Em cada município seriam criados campos e oficinas aos alunos com fim de "habilitar os aprendizes a manejar, com destreza e habilidade, os instrumentos do trabalho, sem prepará-los para um ofício determinado" (FONSECA, 1986, p. 171. Grifo nosso). O anteprojeto não foi aprovado, mas "suas principais sugestões - no que concerne ao ensino industrial" foram adotadas "pela estrutura das Escolas de Aprendizes Artífices" (SOARES, 1981, p. 72-77). Resultava então numa pretensão de não ser uma arte ou ofício, mas práticas elementares, simples, na direção de um ofício.

As quatro escolas profissionais do Estado do Rio forma criadas quando Nilo Peçanha era governador, para "habilitação moral e técnica de menores residentes no estado, de idade entre 9 e 16 anos". Aprenderiam profissões de carpinteiro, sapateiro, correeiro, alfaiate, funileiro, apicultor e jardineiro (SOARES, 1981, p. 69-70).

Para além do caráter correcional,

[...] as Escolas de Aprendizes Artífices dividiam o seu ensino em duas partes principais: uma de cunho teórico - os cursos de letras e de desenho, inicialmente noturnos - e o aprendizado nas oficinas, cujas especialidades em muito pouco diferiam dos ofícios ensinados nas escolas anteriormente analisadas. Além da pobreza - condição necessária para a admissão nessas escolas - os requisitos para a matrícula eram praticamente os mesmos, inclusive a ausência de defeitos físicos que pudessem inabilitar o candidato para o aprendizado de ofícios (SOARES, 1981, p. 76).

Ressalta-se aqui, numa leitura da conjuntura em que foi assinado o Decreto $\mathrm{n}^{\mathrm{o}} 7.566$, que aos alunos não era necessário a aprendizagem de um ofício regular, formal e socialmente reconhecido, pois bastava ocupar, com certa destreza em atividades manuais, os menores desvalidos, para evitar de se tornarem perigosos 
por conta da ociosidade. Ou seja, a instrução manual era um paliativo com caráter moral ao mesmo tempo que produtivo. Na exposição de motivos do Decreto, informa-se a necessidade de "não só habilitar os filhos dos desfavorecidos da fortuna com o indispensável preparo técnico e intelectual, como faze-los adquirir hábitos de trabalho profícuo, que os afastará da ociosidade, escola do vício e do crime" (BRASIL, 1909).

Os objetivos finais destas escolas seriam a formação de operários e contramestres, através do ensino prático em "oficinas de trabalho manual ou mecânico que forem mais convenientes e necessárias no Estado em que funcionar a escola" (BRASIL, 1909).

Em um artigo, de 1982, abordando a estrutura e evolução das Escolas de Aprendizes Artífices, Manoel Soares informa que os decretos e instruções posteriores a sua criação determinam a contratação de "professores" para as aulas do ensino primário e de desenho, e de "mestres" para as oficinas (SOARES, 1982, p. 78). Neste caso, a leitura da conjuntura aponta para a não necessidade de professores nas oficinas, em que a habilidade manual a ser adquirida seria o treinamento suficiente.

Segundo Celso Suckow da Fonseca, apesar de ser um início que se mostrará profícuo, as escolas começaram em "edifícios inadequados e em precárias condições de funcionamento de oficinas" e com pouco eficiência pela "falta completa de professores e mestres especializados" (FONSECA, 1986, p. 182).

Os professores saíram dos quadros do ensino primário, não trazendo, por essa razão, nenhuma ideia do que necessitariam lecionar no ensino profissional. Os mestres viriam das fábricas ou oficinas e seriam homens sem a necessária base teórica, com capacidade, apenas, de transmitir a seus discípulos os conhecimentos empíricos que traziam. Os alunos, esses apresentavam-se às escolas com tão baixo nível cultural que se tornou impossível a formação de contramestres, incluída no plano inicial de Nilo Peçanha (FONSECA, 1986, p. 182. Grifo nosso).

Assim, estas escolas estariam voltadas para a formação em ocupações simples, embora sistemática, pela via de hábitos manuais, práticos, destinada à produção, mas também para a correção.

Tendo em vista o estabelecimento do regime republicano, as correntes de pensamento liberal e positivista privilegiadas nesse contexto, estavam sintonizadas com preceitos do catolicismo, pelos quais o 
Ensino Profissional deveria ser destinado aos desvalidos da sorte, como uma pedagogia de cunho tanto preventiva quanto corretiva (CAIRES; OLIVEIRA, 2016, p. 45).

Até setembro do ano de 1910 foram inauguradas 19 escolas de Aprendizes Artífices, mas não exatamente "em cada uma das capitais dos Estados da República" conforme previa o Decreto original, pois foi alterado pelo Decreto $\mathrm{n}^{\mathrm{o}} 7.763$, de 23 de dezembro de 1909, o que permitiu instalar uma escola fora da capital, de tal modo que o Rio Grande do Sul ficou sem a sua escola naquele ano para dar lugar à inauguração da Escola de Campos, no Estado do Rio de Janeiro $^{2}$. As 19 primeiras foram criadas no Piauí, Goiás, Mato Grosso, Rio Grande do Norte, Paraíba, Maranhão, Paraná, Alagoas, Campos, Pernambuco, Espírito Santo, São Paulo, Sergipe, Ceará, Bahia, Pará, Santa Catarina, Minas Gerais e Amazonas (KUNZE, 2009, p. 19).

As principais profissões ensinadas eram as que encontravam sintonia com setor pouco desenvolvido da nossa indústria, ainda rústica e manualizada: sapataria, marcenaria, alfaiataria, serralheria, funilaria, ferraria, selaria, tipografia, entalhe, correaria, entre outras (SOARES, 1981; CUNHA, 2000b).

A criação das Escolas de Aprendizes Artífices, no entanto, não significou uma integração do trabalho com a educação ou a escolarização do trabalho pelo ensino técnico, muito pelo contrário, as ideias que vigoravam na época continuavam a entender que havia uma desvinculação entre formação profissional e educação, ou seja, entre trabalho e educação. A educação, diferente de ensino profissional, era aquela de base teórica, intelectualista, "voltada para a formação das classes dirigentes, daqueles que iriam ocupar os cargos de comando, ou burocráticos, na sociedade; formação profissional era aquela de base prática, voltada para as classes populares" (GOMES, 2005, p. 2). A visão dualista da educação continuava, o ensino profissional era para "os filhos dos desfavorecidos da fortuna" (MÜLLER, 2010, p. 195).

2 Cada capital dos Estados da Federação receberam uma escola, salvo a instituição fluminense que se instalou no interior do Estado do Rio de Janeiro, no município de Campos, cidade natal do Presidente da República. Para compensar o Rio Grande do Sul, em 25 de outubro de 1911, via Decreto $n^{\circ}$ 9.070, o Instituto Técnico Profissional da Escola de Engenharia de Porto Alegre (depois Instituto Parobé) passou a ser mantido como Escola de Aprendizes Artífices. Tanto a Escola de Campos (RJ) como o Instituto Técnico (RS) eram escolas pré-existentes, que passaram a receber subvenção do governo Federal. 


\section{A inclusão da partícula "E" na oração "Aprendizes Artífices"}

Em maio de 2018, convidado a apreciar uma dissertação, este pesquisador se deparou com o uso da expressão "escola de aprendizes e artífices". Já havia percebido esta discrepância entre o uso no decreto federal e o uso em artigos, dissertações e teses. Objeto de revisão e crítica no presente estudo, naquela ocasião, reportei ao professor Jefferson Araújo Moraes ${ }^{3}$, ser um erro comum entre nós (no qual me incluo) o de colocar este "e". A origem deste equívoco pode ter relação com a arte, ou seja, com a ideia de fazer utensílios com beleza e sofisticação. Pois, antes destas escolas, havia várias escolas no Brasil, do Segundo Império, chamadas "Liceus de Artes e Ofícios". Seguindo esta concepção de formar artífices, cria-se instituições para os iniciantes pobres. Neste caso, o nome reflete uma escola que não era para Ofícios com Arte (que formaria Oficiais e Mestres), mas destinada aos desvalidos iniciantes, ou seja, eram aprendizes da arte. Por isso, APRENDIZES ARTÍFICES.

Esta abordagem explicativa coloquei em suspensão, diante dos estudos do presente artigo, que iremos elucidar na conclusão, mas para tal seguiremos o caminho de análise e posterior síntese dos termos e dos documentos históricos.

Após esta primeira dissertação, em outras bancas de mestrados e doutorados, o mesmo desafio se apresentou. Tivemos que enfrentar outra vez a correção do uso do termo aditivo "e" ao referir-se ao Decreto de Nilo Peçanha. Foi então necessário quantificar o uso, para saber se não estávamos apenas diante de irrelevantes usos equivocados. De outro lado, buscamos apresentar suporte para as correções junto as qualificações de mestrados, doutorados e aos artigos que dizem respeito, além de apontar as implicações semânticas e conceituais que este equívoco representa.

Optou-se por fazer busca de seu uso em meios científicos, jornalísticos, livros e demais textos que circulam no ambiente eletrônico. A Tabela 1 apresenta o resultado quantitativo a partir dos principais buscadores ${ }^{4}$ na rede mundial de computadores. Os termos pesquisados foram colocados inicialmente entre aspas, para serem exatos, tal e qual digitados; algumas frases com "e" e outras sem esta partícula aditiva. Contudo, alguns buscadores apresentavam resultados

3 Autor do texto preparatório da dissertação (IFPR).

4 Foram utilizadas informações oriundas da Revista EXAME. Disponível em: https:// exame.abril.com.br/tecnologia/google-brasil-segue-no-topo-entre-os-buscadores/. Acesso em: 12 maio 2019 e do Blog NEILPATEL. Disponível em: https://neilpatel.com/br/blog/sites-de-busca/. Acesso em: 12 maio 2019. 
assemelhados e não exatos, mesmo usando esta regra. Nestes, foi acrescentada a frase que não deveria ser buscada com o uso do recurso $\mathrm{NOT}^{5}$, ou seja, determinada frase não era para ser buscada. Assim o resultado foi apurado.

TABELA 1 - BUSCAS DOS TERMOS NOS PRINCIPAIS BUSCADORES NA REDE MUNDIAL DE COMPUTADORES

\begin{tabular}{lccccc}
\hline Termos & Google & Bing* & Yahoo* & AOL.com* & Média \\
\hline "escolas de aprendizes artífices" & 17.400 & 7.110 & 11.100 & 13.800 & 12.353 \\
"escolas de aprendizes e artífices" & 8.310 & 3.090 & 3.100 & 5.440 & 4.985 \\
"aprendizes artífices" & 36.100 & 21.000 & 21.600 & 21.500 & 25.050 \\
"aprendizes e artífices" & 11.200 & 3.830 & 4.710 & 3.920 & 5.915 \\
Corretos & & & & & $\mathbf{2 4 . 8 7 8}$ \\
Equivocados & & & & & $\mathbf{7 . 9 4 3}$ \\
\hline
\end{tabular}

Obs.: Os buscadores "Ask.com" e "Baidu" não retornam a soma de resultados. Estes dois sites estão em quarto e sexto lugares, respectivamente, entre os mais usados mundialmente.

* Para eliminar resultados somados ou indesejados usou-se o NOT. Ex. "aprendizes artífices" NOT "aprendizes e artífices".

FONTE: Dados coletados pelo autor em: 12 maio 2019.

Pela análise estatística dos resultados obtidos, infere-se que ao menos um terço das pessoas utilizaram a expressão contida no Decreto de Nilo Peçanha de forma equivocada.

Para cada três referências, uma teve estes problemas, o que confirma que aqueles que usam os termos com a partícula "e" o fazem, hipoteticamente, por um valor novo do ponto de vista linguístico e por desconhecer a significação conjuntural da expressão original. Com o fim de contribuir para este esclarecimento, é importante situar então tanto a palavra "aprendizes" e a palavra "artífices" no seu tempo e a partícula "e" no sentido semântico diacrônico. ${ }^{6}$

Esta análise toma por base o método histórico de verificar diferenças de significação à luz do significado real ou de uso do termo em cada época. Isso

5 Os operadores booleanos (de George Boole), são opções lógicas para definir o que se busca. São AND, OR e NOT (E, OU e NÃO). Neste caso a busca "não" aceitaria outros termos, a não ser exatamente ao que se pedia.

6 No estudo da linguística a disciplina da semântica estuda o significado de palavras, frases e textos no contexto de uma língua. Pode ser descritiva, ou seja, sincrônica com o tempo atual de seu sentido conceitual ou diacrônica, ou seja, o significado e mudanças em distintos tempos históricos. $\mathrm{O}$ diacronismo permite entender a expressão no tempo em que foi veiculada. 
evita o anacronismo em adotar as significações atuais para temas de época pretérita. Nossa contribuição, mais histórica que linguística, está em sintonia com a necessidade de entender a língua como elemento vivo, superando preconceitos de seu uso e para dar-lhe valor como objeto identificador da historicidade humana, pois "pouco ou nenhum espaço é dado a fenômenos de mudança linguística, representativos da chamada variação diacrônica ou histórica" e que este trato não se restrinja aos estudos em língua portuguesa (AMORIM, 2018, p. 52. Grifo no original).

\section{Artífices}

Optamos por analisar primeiro a palavra artífice, pois o termo aprendizes, no contexto do Decreto tem função de adjetivo, ou seja, coloca uma qualidade na principal palavra da oração. Ao entendermos a conjuntura e a semântica da palavra artífice, comparando com a categoria dos "oficiais", passamos a entender mais facilmente a função do termo "aprendizes".

A cultura ocidental passou por momentos em que desvalorizava o esforço físico e o emprego das mãos para produção de objetos e serviços para a sobrevivência cotidiana. Em outras ocasiões, deu-se valor ao trabalho manual quando ligado ao valor moral de combate ao ócio, a depender também da posição da pessoa que o executava ou conforme a atividade manual emprega maior ou menor conhecimento científico ou tecnológico. Neste contexto é que iremos descortinar o significado de artífice.

$\mathrm{Na}$ Grécia antiga as atividades possíveis ao ser humano eram divididas em práxis e poiesis. A primeira expressão corresponde às atividades da ação, em que a pessoa e a ação não se separam no processo, ou seja, o agente, o ato realizado e a finalidade do ato são idênticos. Exemplo disso é a política e a ética.

As atividades ligadas à fabricação correspondem ao termo poiesis. Neste caso temos artes e técnicas. A palavra técnica vem do grego téchne e tem seu equivalente em latim na palavra ars. Até o século XVIII não havia distinção entre arte e técnica, inclusive no Brasil. Ambas significavam a intervenção possível do ser humano na natureza, para modificá-la ao seu interesse. Sob domínio romano passou a haver uma diferença entre as artes que modificavam a natureza e aquelas, como a música e a retórica, que eram para modificar o próprio homem.

Para Milton Vargas, a palavra "téchne tem uma extensão maior que a latina ars, pois que pressupõe uma conduta certa numa atividade específica subordinada a uma série de conhecimentos adquiridos através de educação" (VARGAS, 1992, p. 99). 
Por conta do regime escravista, tanto na cultura grega clássica como no Império Romano, as atividades práticas com o uso de técnicas e artes passam a ser desvalorizadas. Para os gregos a contemplação era digna dos cidadãos, enquanto que a ação era para os escravos.

A classificação das técnicas ou artes seguirá um padrão determinado pela sociedade antiga e, portanto, pela estrutura social fundada na escravidão, isto é, uma sociedade que despreza o trabalho manual. Uma obra, As núpcias de Mercúrio e Filologia, escrita pelo historiador romano Varrão, oferece a classificação que perdurará do século II d.C. ao século XV, dividindo as artes em liberais (os dignas do homem livre) e servis ou mecânicas (próprias do trabalhador manual) (CHAUÍ, 2000, p. 405).

No início da expansão romana, devido ao cultivo da terra por homens livres, o chamado labor tinha um valor positivo. Com a expansão do império, vastas terras passaram a ser cultivadas por prisioneiros e povos dominados, em regime de escravidão. Novamente a atividade manual passou a ser vista como vil, e, ao invés de labor, passou a ser o desprezível "tripalium" (instrumento de tortura de três paus), ou trabalho (CUNHA, 2000a, p. 9).

Com o colapso do Império Romano e a extensa ruralização feudal, os mosteiros religiosos mostraram-se como locais de aprendizagem prática de artesanato e outros trabalhos manuais, dentro dos quais "o ócio passou a ser definido como o pai dos vícios", o novo sentido e, neste espaço, a atividade manual passa a ter um sentido positivo, "mais moral do que propriamente produtiva" (CUNHA, 2000a, p. 11). Assim sendo, a partir do século XI, os burgos (núcleos urbanos) passam a ter os artesãos e surgem as corporações de ofício, para sua proteção e valorização da atividade manual. Nos mosteiros e nas corporações, o trabalho manual era "confinadamente" prestigiado.

"A antiga distinção de atividades nobres e ignóbeis foi refeita no âmbito das
corporações entre os que cultivavam as artes liberais e as artes mecânicas.
As artes liberais eram as atividades dos homens livres", ou seja, libertos
da imposição "de ter que trabalhar para viver" (CUNHA, 2000a, p. 12).

No Renascimento, além da diferença social acima descrita, passou a ter diferença segundo a finalidade, qualidade e o tipo de atividade. Aquele que 
trabalhava identificado pela genialidade pessoal pública, independente de proteção profissional, era o artista. "O artista é visto como dotado de inspiração, entendida como uma espécie de iluminação interior e espiritual misteriosa, que leva o gênio a criar a obra" mais preocupado com o belo do que com o útil (CHAUÍ, 2000a, p. 407). Aquele que está mais preocupado com o útil do que com o belo será o artífice. O artífice "continuava em seu trabalho anônimo, restrito ao âmbito da corporação de ofícios, que constituía, ao mesmo tempo, uma atenuação de seu enfraquecimento diante das novas condições" do nascente sistema manufatureiro-capitalista (CUNHA, 2000a, p. 12).

Os ofícios mecânicos passam a ter menor valor sendo substituídos pelas novas manufaturas, ávidas por trabalho livre. A depreciação do trabalho manual passou dos países ibéricos para o Brasil, aqui somando-se à existência da escravidão, aviltando ainda mais as atividades manuais e aqueles que trabalhavam com esforço físico.

Na Península Ibérica, onde o artesanato não floresceu como no restante da Europa, vemos o valor social conferido ao trabalho manual ser especialmente depreciado. A rejeição do trabalho manual parece ter sido comum tanto à cultura portuguesa quanto à espanhola (CUNHA, 2000a, p. 13).

Assim, do grego téchne ou do latim ars (arte) na Antiguidade, até o século XVIII, arte era técnica que significava utilizar a natureza em favor dos seres humanos. A partir de então diferenciou-se a arte da técnica: a primeira tornou-se belas-artes (pintura, escultura, música, teatro), e a segunda, a ação humana para transformar e dominar a natureza. As palavras até hoje usadas, como artífice, artificial e artefato, preservam identidade antiga entre arte e técnica; num trocadilho: o artesão usa um artifício para fazer o artefato. Estas palavras também traduzem uma significação sociocultural vil, qual seja o do trabalho manual.

Desde o início da colonização do Brasil, as relações escravistas de produção afastaram a forma de trabalho livre do artesanato e da manufatura. O emprego de escravos como carpinteiros, ferreiros, pedreiros, tecelões etc. afugentava os trabalhadores livres dessas atividades, empenhados todos em se diferenciar do escravo [...] os ofícios mecânicos passavam a ser desprezados, como se houvesse algo de essencialmente aviltante no trabalho manual, quando a exploração do escravo é que o era (CUNHA, 2000a, p. 16). 
Desta forma se construiu a significação do termo "artífice", ou seja, uma pessoa que trabalha com esforço físico, com as mãos, em ofícios mecânicos, distinguido daqueles que exercem atividades, mesmo com as mãos, mas que requerem educação, refinamento e inspiração, que serão os filhos dos mais abastados, ligados às artes liberais, mais tarde chamadas de Belas-Artes.

Aos artífices, que também passam a ser chamados de operadores ou operários no sistema capitalista, não eram necessários refinados estudos, mas práticas de oficinas. Este entendimento, mundo afora, determinava que o sistema educacional não era para todos. Havia, sim, necessidade de instrução, mas cada tipo de ensino destinado a determinado público, pelo critério socioeconômico e tendo em vista a valorização social da atividade e do tipo de pessoa a quem a atividade está ideologicamente reservada; exercer trabalho penoso manual, por exemplo, é destinado aos pobres ou de classe inferior.

A decisão política de interdição ao acesso à educação às classes baixas, reservando para elas apenas os ofícios mecânicos, podemos ver nas seguintes transcrições.

$\mathrm{Na}$ Inglaterra:

Um tal Mr. Giddy, diz Niebhur, que foi posteriormente presidente da sociedade real, fez objeções (refere-se ao projeto de lei que se apresentou ao Parlamento britânico em 1807, criando escolas subvencionadas) que se podiam ter apresentado em qualquer outro país: "Por especial que pudesse ser em teoria o projeto de dar educação às classes trabalhadoras dos pobres, seria prejudicial para sua moral e sua felicidade; ensinaria a desprezar sua missão na vida, em lugar de fazer deles bons servos para a agricultura e outros empregos; em lugar de ensinar-lhes subordinação os faria rebeldes e refratários, como se pôs em evidência nos condados manufatureiros; habilitá-los-ia ler folhetos sediciosos, livros perversos e publicações contra a cristandade; torná-las-ia insolentes para com seus superiores e, em poucos anos, se faria necessário à legislatura dirigir contra eles o braço forte do poder" (NIEBHUR, 1960 apud FREIRE, 1987, p. 73. Grifo nosso).

Na França, no início do século XIX, houve a defesa de uma educação dual por Destutt de Tracy, conde, naturalista e organicista, que preconizava dois sistemas educacionais distintos: um para os filhos da classe operária, para adquirirem desde cedo hábitos e habilidades ao trabalho manual, e outro, para a elite, que deveria estudar por muito tempo, visto que deveria exercer o poder na sociedade. Isto porque, segundo descreve Destutt de Tracy, em 1802: 
Em toda sociedade civilizada existem necessariamente duas classes de pessoas: a que tira sua subsistência da força de seus braços e a que vive da renda de suas propriedades ou do produto de funções onde $\mathbf{0}$ trabalho do espírito prepondera sobre o trabalho manual. A primeira é a classe operária; a segunda é aquela que eu chamaria de classe erudita. Os homens da classe operária têm desde cedo necessidade do trabalho de seus filhos. Estas crianças precisam adquirir desde cedo o conhecimento e, sobretudo o hábito e a tradição do trabalho penoso a que se destinam. Não podem perder tempo nas escolas [...] os filhos da classe erudita, ao contrário, podem dedicar-se a estudar durante muito tempo; têm muita coisa a aprender para alcançar o que se espera deles no futuro. Necessitam de um certo tipo de conhecimento que só se pode aprender quando o espírito amadurece e atinge determinado grau de desenvolvimento (TRACY, 1917, p. 67, apud SILVA; ARRAES NETO; SILVA, 2012, p. 26. Grifo nosso).

No Brasil, no final do século XIX:

Lebreton alertava para que não se repetissem, no Rio de Janeiro, os defeitos da Academia de Belas-Artes de Paris que, por ser gratuita, recebia os filhos dos pobres, sem talento. Estes deveriam ser encaminhados para o aprendizado de ofícios mecânicos, evitandose, assim, que esse "fermento grosseiro" contaminasse as belas-artes (CUNHA, 2000a, p. 79. Grifo nosso).

O surgimento de uma escola profissional no Brasil, para formar artífices os meninos oriundos de classes pobres, por serem as atividades mecânicas vis, está numa época em que já existiam os Liceus de Artes e Ofícios. Contudo, veremos, a escola não formaria oficiais, mas auxiliares destes ou aprendizes de artífices. Se formar oficiais ou artífices já era uma formação depreciada, tanto mais será, nesta conjuntura, formar arremedo destes ou seus auxiliares. Contudo, o Decreto e as normas indicavam a vontade política de que os estudantes aprendessem para serem artífices. Partimos então para entender a separação existente entre a aprendizagem das artes liberais e mecânicas nas instituições que passaram a existir na segunda metade do século XIX no Brasil. 


\section{Os oficiais nos liceus}

Neste tópico mostraremos que, nas artes liberais (belas-artes) e nas artes mecânicas, há uma escala de prestígios, de acordo com a atividade escrutinada para determinadas pessoas na sociedade. O mais alto prestígio está com os artistas das belas-artes. Em seguida estão os mestres em profissões mecânicas, depois os oficiais, conforme anota um dicionário da época: “Aquele que, exercendo um ofício, tem categoria inferior à de mestre: oficial de serralheiro" por exemplo (FIGUEIREDO, 1913, p. 1421). Com prestígio socioeconômico inferior ao oficial estão os contramestres e os operários, duas categorias de artífices.

A partir de 1840 no Brasil, são criadas 10 instituições de caráter filantrópico, destinadas aos meninos pobres e órfãos. São as Casas dos Educandos Artífices no Pará, Maranhão, São Paulo, Piauí, Alagoas, Ceará Sergipe, Amazonas, Rio Grande do Norte e Paraíba. Também foram criados asilos para meninos desvalidos e casas pias. Estas instituições eram de caráter assistencialista mantidas pela caridade, mormente privada.

Em 1855 surge a Academia de Belas-Artes, para o ensino de ofícios, mantida pelo estado. "Os alunos da academia eram divididos em dois grupos: os artistas, que se dedicavam às belas-artes, e os artífices, que professavam as artes mecânicas" (CUNHA, 2000a, p. 119). Assim como a Academia de BelasArtes, também havia cursos de nível superior oferecidos pela Escola Politécnica, instituição civil criada em 1874, para formação de engenheiros ${ }^{7}$ não militares, assim chamados engenheiros civis, sendo a "primeira escola de engenharia do país” (MACEDO; SAPUNARU, 2016, p. 44).

A engenharia estava desde a Renascença separando a atividade manual da puramente teórica-literária ${ }^{8}$ " "Para os engenheiros do Renascimento não havia distinção entre trabalho técnico e artístico" (GUERRA; BRAGA; REIS, 2004, p. 35). Neste caso, seria uma atividade manual com certa nobreza, pois

8 "A conjunção da ciência com a técnica" no início da modernidade foi "muito malsucedido". $\mathrm{Na}$ metade do "século XVIII desenvolveu-se a engenharia como aplicação de conhecimentos científicos" em obras, utensílios e materiais (VARGAS, 1994, p. 16).

7 No Renascimento, trabalhadores manuais "de construtores de pequenos moinhos" ou engenhos, passaram a construir catedrais e usar sofisticados instrumentos de medição e a matemática nos "projetos da nascente burguesia". "O trabalho manual [...] passou a desempenhar papel decisivo no contexto desses projetos". Muitos destes construtores de engenhos eram homens sem letras (sem filosofia e teologia). (GUERRA; BRAGA; REIS, 2004, p. 33). 
estava vinculado a quem fazia - uma pessoa com bastante escolaridade que iria dirigir os trabalhos manuais feitos por mestres, oficiais e artífices. Assim como estava se tornando nobre a atividade do cirurgião ${ }^{9}$ a ser feita por médicos. Não se tratava de "mera discriminação do trabalho manual das demais atividades sociais, mas, também e principalmente, a daqueles que o executavam". Se determinada atividade "manual não fosse socialmente" tida com desprestígio, ela "não seria objeto de rejeição, como acontece atualmente com o trabalho do cirurgião" (CUNHA, 2000a, p. 23).

Em 1856 surgiu o Liceu de Artes e Ofícios do Rio de Janeiro, com a pretensão de "quebrar a dicotomia: bacharelismo versus analfabetismo e implantar um segmento intermediário de estudo que permitisse o exercício profícuo e digno de uma profissão nos diversos ramos das chamadas artes industriais e artes menores" (BIELINSKI, 2009, p. 2). Era de caráter filantrópico, fundado por burocratas e comerciantes, com os professores ensinando gratuitamente e mantido com doações. Eram atendidos "menores", adultos e mulheres trabalhadores, era gratuito, noturno e "de ensino elementar, técnico-profissional e artístico", alfabetizando-os no desenho para as artes e no desenho industrial. Serviu de modelo para o surgimento de outros Liceus pelo Brasil (BIELINSKI, 2009, p. 6-9).

Segundo Luiz Antônio Cunha, a "academia foi criada para ser uma escola superior, enquanto que o liceu era a "escola do povo", uma era para a aristocracia e a outra era para as inteligências acanhadas trabalharem em oficinas úteis, "a academia fora se especializando mesmo na formação dos artistas, da 'aristocracia do talento', deixando a cargo de outras instituições a formação das 'inteligências modestas', isto é dos artífices” (CUNHA, 2000a, p. 120). Segundo o "Novo Diccionário da Língua Portuguesa" de Candido de Figueiredo, de 1913, o termo Liceu significa "Instituto oficial de instrução secundária. Ext. Colégio ou estabelecimento particular de instrução secundária. (Lat. lyceum)". (FIGUEIREDO, 1913, p. 1191).

Nos Liceus, o ensino de artes correspondia, nesta conjuntura, às belas-artes: música, desenho elementar e de máquinas, arquitetura, estatuária, escultura, xilografia, pintura e arte em cerâmica. Os ofícios praticamente não existiam, pois não havia recursos suficientes para as oficinas práticas e nem para contratar mestres de ofício. Por não dispor de oficinas, os liceus eram só de artes, sendo que o do Amazonas não era nem de ofícios e nem de artes; "até o fim do período imperial, o ensino propriamente profissional deixava muito a desejar" (CUNHA, 2000a, p. 135).

9 A partir do século IV a. C., com o amplo emprego do trabalho escravo e "a consequente depreciação social de todos os trabalhadores" teve como efeito o divórcio "da cirurgia (operação com as mãos)" da medicina (CUNHA, 2000, p. 8-9). 
Destaca-se que na virada do Brasil imperial para o republicano o traço dominante era

a predominância da cultura intelectual, representada pelas profissões liberais, sobre qualquer outra forma de instrução, principalmente sobre a que se baseava no emprego das mãos. Só a instrução geral e literária era considerada nobre. Aquela, porém, que visava ao preparo do trabalhador manual era tida como vil (FONSECA, 1986, p. 160).

Por conta desta cultura literária antimanual, os liceus não formavam mestres ou oficiais, muito menos contramestres ou operários.

Os artífices no Brasil estavam sendo formados no Asilo dos Meninos Desvalidos, nas Casas de Educandos Artífices e na Escola Industrial. "A instrução dos artífices não era vista como objetivo apenas econômico, mas, também, político-ideológico [...] uma função moralizadora" (CUNHA, 2000a, p. 137). As profissões dos artífices eram: carpinteiros, pedreiros, alfaiates, caixeiros, marceneiros, serventes, ferreiros, maquinistas, sapateiros, serralheiros, caldeireiros, latoeiros, entre outras atividades de serviços e produção de artefatos.

Em resumo: um artífice, no início da república era uma pessoa de classe pobre, com rudimentos de escolarização, que produziria artefatos ou objetos de utilidade cotidiana, com certa destreza manual. A palavra artífice, derivada do latim ars, que por sua vez vem do téchne grego, referia-se ao uso da técnica manual para produção de coisas úteis aos seres humanos. Com o tempo as artes passaram a duas categorias: as liberais e as mecânicas. Os artífices derivaram das mecânicas, mas ainda não eram ofícios, que seriam as artes mecânicas superiores, refinadas, a serem aprendidas nos Liceus. Artífice, portanto, seria menos prestigiado que os poucos oficiais formados, que, por sua vez, eram inferiores aos artistas liberais formados em Belas-Artes dos Liceus.

Segundo o "Novo Diccionário da Língua Portuguesa" de Candido de Figueiredo, de 1913: "Artífice m. Aquelle que exerce uma arte mecânica. Operário. Autor de um artefacto. Inventor. (Lat. artifex).” (FIGUEIREDO, 1913, p. 223).

As academias, para cursos superiores, não formavam nem mestres nem oficiais. Os liceus, que eram para formar oficiais e artistas, formavam basicamente artistas. Pela lógica do governo, era preciso formar contramestres e operários para a nova realidade econômica brasileira, sem enfrentar a posição política enciclopédica-literária da elite nacional, visto que destinou esta tarefa aos pobres e desvalidos, consolidando o fato de que qualquer filho de classe alta estaria em franco desprestígio se frequentasse uma escola que preparasse operários e contramestres, ou seja, artífices. 


\section{Aprendizes}

Seguindo esta concepção de formar artífices, criam-se instituições para os iniciantes pobres. Neste caso, o nome reflete uma escola que não era para aprender os ofícios que formavam oficiais e mestres, mas era destinada aos desvalidos iniciantes, ou seja, eram aprendizes dos ofícios. Por isso, as Escolas de Aprendizes Artífices não formavam artistas ou oficiais, somente profissões inferiores a estas.

Segundo um dicionário de 1913, o termo ofício era deveras uma profissão: "Dever; obrigação natural. Incumbência. Destino especial. Cargo pessoal; profissão: ofício de chapeleiro. Ocupação. Alcofa para ferramentas de sapateiro" (FIGUEIREDO, 1913, p. 1422).

Aqueles que estudavam e praticavam as "ars" passaram a se chamar artistas das belas-artes - seus praticantes socialmente mais valorizados e, em geral, ligados à elite: escultores, pintores, desenhistas, músicos etc. Os que estudavam um ofício da "techné" eram de classe socioeconômica inferior, que teriam uma formação manual para serem artesãos, técnicos, oficiais mecânicos e mestres. Os desvalidos, órfãos e demais pobres, quando tinham opção de escola, era para serem operários, contramestres, oficineiros ou auxiliares. Estes eram aprendizes de um ofício, na direção de serem futuramente um oficial ou mestre.

O decreto que criou as Escolas de Aprendizes Artífices dizia que eram "destinadas ao ensino profissional primário" e que "procurará formar operários e contramestres" (BRASIL, 1909). Pelo dicionário da época um contramestre era um "Empregado de navio, imediatamente inferior ao mestre. Artífice, que substitui o mestre. (De contra... + mestre). (FIGUEIREDO, 1913, p. 515). Portanto está claro que a formação era equivalente ao que chamamos hoje de "auxiliar". Mas, no uso da linguagem, se pergunta, mas auxiliar de que ou de quem? Seria um auxiliar de um mestre, auxiliar de uma determinada profissão ou ofício.

Neste caso o termo "aprendizes" tem uma função adjetiva. Aprendizes de algo ou que está aprendendo na escola para ser um artífice. Mas se atentarmos para o que diz FONSECA (1986, p. 182), pelas condições das oficinas, dos professores e mestres, nem contramestres eram formados. Praticamente estas escolas formavam operários, categoria de profissional na mais baixa escala socioeconômica e cultural da época. Só estava acima dos analfabetos e que não possuíam qualquer habilidade manual específica.

Faz-nos compreender que, na época, a significação sociocultural era de que tratava-se de estudantes para serem artífices, ou seja, estudariam para serem auxiliares de um mestre ou oficial, seriam, portanto, operários e contramestres, 
segundo a vontade do Decreto, embora a realidade nas escolas só permitisse a formação de operários.

Segundo o "Novo Diccionário da Língua Portuguesa" de Candido de Figueiredo, de 1913: "Aprendiz m. Aquelle que aprende offício ou arte; principiante. Aquelle que é pouco intelligente ou que tem pouca experiência. Primeiro grau da Maçonaria. (B. lat. apprehendivus). (FIGUEIREDO, 1913, p. 191). O "pouco inteligente" treinado poderia se tornar operário.

\section{A partícula "E"}

É um equívoco colocar este "e". Falar em Escola de Aprendizes "e" Artífices parece ser o mais adequado nos dias de hoje, visto que o termo aprendiz ganhou função substantiva, ou seja, aquele que está trabalhando para aprender uma atividade, na prática. Mas, se compararmos o seu significado na época é o mesmo que falar em uma Escola de Aprendizes "e" Técnicos, quando na verdade se queria dizer "aprendizes técnicos" ou "aprendizes de técnico". Convenhamos, existe uma diferença grande entre uma escola que só tem iniciantes de determinada profissão, ou auxiliar desta, e uma que tem iniciantes e preparação de oficiais ou técnicos.

O desafio é entender a mudança conceitual que está em se adicionar inopinadamente a partícula "e" quando o Decreto original não a tinha, visto que havia um significado socioeconômico importante subjacente. Outro esforço teórico é entender linguisticamente fatores que levam um terço dos usuários daquela expressão a utilizar a partícula aditiva "e" com certa naturalidade.

Sobre um adjetivo, conceitua-se como uma categoria de palavras que dão qualidade ao substantivo, ou seja, "é a palavra que se junta ao substantivo, atribuindo-lhe uma qualidade; tem, na oração, a função sintática de se juntar a um substantivo para lhe restringir o sentido" (OLIVEIRA E SILVA; RAVANELLI, 2008, p. 2). Enquanto o advérbio é imutável, o adjetivo, assim como o substantivo

[...] é uma palavra variável e pode ainda ser colocado antes ou depois do substantivo, mas, conforme a posição que ocupa na frase, sua significação se altera. Por isso, pode-se afirmar que, quando o adjetivo está logo depois do substantivo, tende a conservar o valor próprio, objetivo; quando está antes, tende a perder o próprio valor e a adquirir um sentido afetivo (OLIVEIRA E SILVA; RAVANELLI, 2008, p. 2). 
Tender logicamente ao uso da partícula "e" se deve hodiernamente a sua facilidade em suportar mudanças; assim, o "aprendiz" que é transitório, equivalente a estudante (que é uma fase da vida da pessoa), que caracteriza o principal do ser permanente "artífice".

Sobre este último aspecto, avaliamos o fato de o termo "aprendiz" ter ganho função substantiva ao longo do tempo no uso da língua portuguesa. Cunha e Cintra esclarecem que "a maioria dos adjetivos é constituída por aqueles que derivam de um substantivo ou de um verbo, com os quais continuam a relacionar-se do ponto de vista semântico" (2017, p. 262). Com efeito, pela lógica da construção mental, trocar uma função adjetiva por substantiva não causa estranheza lógica e o usuário da língua normaliza seu uso.

Para esta normatização, acusamos um dos fatores: a ampliação da educação formal no Brasil, desde 1909, em que muitos passaram a ser aprendizes de muitas cosias. Em todo momento sendo aprendiz, tornou mais perene e frequente seu uso cotidiano, portanto substantiva a sua significação. Tanto que, há pouco tempo, tivermos uma Lei nacional chamada "menor aprendiz" (BRASIL, 2000), em que o substantivo aprendiz ganhou força, sobretudo quando se refere à qualidade da pessoa que ainda está na minoridade (qualidade de ser menor). Contudo, o termo aprendiz pode ser intercambiável para substantivo, tanto que a mesma Lei usa "o aprendiz" como substantivo absoluto.

A diminuição da função adjetiva para substantiva percebemos ao analisar a partícula aditiva no meio da oração. A partícula "e" na língua portuguesa, segundo Rocha Lima (2010), tem um valor primitivo de adição, mas tem valor particular no interior de uma oração (ou intra-oracional, no nosso caso), entre orações e no início de frase.

Portadora de significação puramente virtual, encorpa-se de significação real em cada uma dessas estruturas, por força do poder imantador do contexto. E muitas vezes passa a assumir o papel de polo semântico da construção onde se encrava - e de modo tão avassalador que não pode ser desta suprimido (ROCHA LIMA, 2010, p. 10).

O autor anuncia que a partícula "e" tem aspecto psicológico, estilístico e semântico e passa a estudá-la através de estruturas-tipos, para análise. $\mathrm{Na}$ estrutura da oração "Não nascemos para ser marido e mulher", ele revela: 
Habitualmente, os termos enlaçados por e aditivo estão no mesmo nível de equilíbrio e importância. A sequência $a+b$ identifica-se, no plano abstrato do raciocínio matemático, com a sequência $b+a$. Realmente, tanto monta dizer Comprei cravos e rosas como Comprei rosas e cravos (ROCHA LIMA, 2010, p. 25).

Neste caso, para aqueles que utilizam "aprendizes e artífices" poderíamos propor o exercício de troca "artífices e aprendizes" em que se percebe ambos adjetivos e na mesma hierarquia de importância como soma aritmética. Contudo o autor adiante informa que "do ponto de vista psicológico, $\mathrm{a}+\mathrm{b}$ não se equipara a $\mathrm{b}+\mathrm{a}$ ", em que alguns autores alegam motivos de natureza social, e isto explica "a razão de, em certas sequências, a língua impor uma ordem fixa, em que os elementos componentes se dispõem hierarquicamente" (ROCHA LIMA, 2010, p. 26). Dá como exemplo comum de uso hierárquico da partícula as orações "pai e filho" e "Senhor Fulano de Tal e Senhora". "Nessas fórmulas, sentimos, de modo flagrante, o desnivelamento (psicológico) existente entre a e b" (ROCHA LIMA, 2010, p. 28).

Com efeito, ao transferir a partícula aditiva para nosso caso, no uso equivocado atual, deveríamos hierarquizar e utilizar "artífices e aprendizes". Do ponto de vista lógico, não estabeleceria coerência com a intenção do governo, ao estabelecer numa norma escrita a política de formação profissional, em que ser aprendiz de algo seria mais importante que ser reconhecidamente um artífice, pois politicamente não seria adequado.

\section{Professores, mestres e o ensino aos artífices}

O Decreto $n^{0} 7.566 / 1909$ previa a instalação em cada Escola de Aprendizes Artífices de até "cinco oficinas de trabalho ou mecânico que forem mais convenientes e necessárias no Estado em que funcionar a escola" (BRASIL, 1909) e teriam obrigatoriamente dois cursos à noite: para os analfabetos, um curso primário e, para os que não sabiam desenhar, um curso de desenho, conforme a necessidade da atividade mecânica que irá aprender. "Mais tarde, a obrigatoriedade destes cursos se estendeu a todos os alunos" (SOARES, 1982, p. 61).

Para os estudos de desenho e ensino primário as escolas tinham professores, enquanto, para as aulas práticas nas oficinas, tinham mestres. Eis uma diferença importante quanto aos padrões atuais. Os professores dariam aula noturna enquanto os mestres trabalhariam ensinando nas oficinas durante o dia (MEDEIROS NETA; NASCIMENTO; RODRIGUES, 2012, p. 98). Já em 
1911, devido à baixa qualidade dos professores e mestres, isso levou o governo a baixar o Decreto $n^{\circ} 9.070$ :

A gravidade da situação do professorado e da mestrança levou o regulamento de 1911 a exigir para os cursos primários e de desenho professores de "comprovada competência", assim como permitir o contrato, no país ou no estrangeiro, de "profissionais de reconhecida competência para dirigirem as oficinas". Em 1918, o Regulamento Pereira Lima ratifica essas exigências e acrescenta que o provimento dos cargos de professores e adjuntos de professores e de mestres e contramestres seja feito mediante concurso de provas práticas, presididas pelo diretor da escola e de acordo com as instruções que para tal fim forem expedidas. (SOARES, 1982, p. 78).

Mesmo os professores normalistas atuando na alfabetização tinham certa dificuldade para atuar na escola, pois, além da leitura, escrita e aritmética, deveriam ensinar desenho:

[...] os professores que passariam a atuar nesse curso tinham como objetivo alfabetizar esses alunos, em que os saberes para ensinar e os saberes a ensinar do modelo normal supririam a demanda do curso primário. Mas (...), o trabalho deste professor se estenderia para além da alfabetização. Caberia à instituição formar os alunos para a prática, aproximando os conhecimentos obtidos no curso primário com conhecimentos técnicos (BARBARESCO, 2019, p. 73).

Quanto aos mestres, estes tinham baixa formação e pouca experiência didática (FONSECA, 1986) e atuavam em cada uma das 5 oficinas de trabalho manual. Os "ofícios a serem ensinados nas diversas escolas não obedeceram a nenhum critério industrial, nem tampouco visavam à adaptabilidade às indústrias locais [...] em matéria de ensino das profissões, um completo desastre" (LUDERITZ, 1925, p. 144).

Em 1917aEscola NormaldeArtese Ofícios VenceslauBrás, no DistritoFederal, é designada com a finalidade de "preparar professores, mestres e contramestres para os estabelecimentos de ensino profissional" (SOARES, 1982, p. 85). Esta experiência não teve tanto êxito em suprir as demandas de professores nas oficinas profissionais do país. A Escola fechou em 1937. Os mestres foram muito lentamente sendo substituídos por professores técnicos e engenheiros. 
Apesar de a realidade não indicar uma formação adequada para os alunos que acessavam as Escolas de Aprendizes Artífices, visto a precariedade dos professores e dos poucos mestres capacitados, a intenção política da norma federal, o Decreto $\mathrm{n}^{\circ} 7.566$, não era formar aprendizes mas, enquanto estavam na escola, eram aprendizes de um ofício. Não se formaria um oficial ou mestre, mas um operário ou contramestre. Do ponto de vista semântico, a significação da escola de aprendizes artífices também era essa, ou seja, ser aprendiz enquanto estava na escola, saindo com uma formação manual, reconhecida pelo menos formalmente.

Em abril de 2012, na Escola de Aprendizes Artífices de Natal, ocorreu a solenidade de premiação dos estudantes dos trabalhos expostos anualmente pelos mesmos, conforme previa o Artigo 12 do Decreto 7.566/1909. Observamos que é citado que o estudante é aprendiz de uma profissão:

O primeiro prêmio recebeu o nome Rio Branco, o segundo o nome Pedro de Toledo e o terceiro o nome Alberto Maranhão. O aprendiz de marceneiro Inocêncio Manoel do Nascimento recebeu o primeiro prêmio; $o$ aprendiz de alfaiate Salvador Carneiro recebeu o segundo prêmio. $\mathrm{O}$ terceiro prêmio, que homenageava o Governador do Estado, foi recebido pelo aprendiz de sapateiro Elói Marques do Nascimento (MEDEIROS NETA; NASCIMENTO; RODRIGUES, 2012, p. 98. Grifo nosso).

Com o levantamento destas informações, em relação às profissões e ao seu desenvolvimento em instituições formais, foi possível fazer uma análise crítica em relação ao uso dos termos em uma visão semântica diacrônica, com o que concluímos nosso artigo.

\section{Conclusão}

Atualmente, o termo aprendiz tem mais sentido substantivo pois é aprendiz de alguma técnica, atividade, teoria ou doutrina. Neste sentido, nossa intuição lógica inclina-se para informar que temos aprendizes e artífices. Contudo, no contexto da época, o termo "aprendizes" tem função adjetiva. Não separava em duas formações, era uma só, então era um curso preparatório para formar artífices, que era uma profissão importante, com valor social superior entre as atividades não intelectuais. 
Ao governo, quando impulsiona uma política, não interessa, sob o ponto de vista do apelo popular, que a obra ou a instituição seja desimportante. Com efeito, o decreto queria dar à sociedade uma escola em que "aprendizes" adentrariam nela e sairiam "artífices". Não era para preparar duas classes ou tipos de profissionais, mas uma só: artífices.

Atualizando os termos do ponto de vista semântico diacrônico é equivalente a dizer que tenhamos uma escola para estudantes técnicos ou "aprendizes", que se formariam como técnicos. Apesar da pretensão legal, semântica e política da época, a realidade que estudamos mostrou que esta formação, com tal qualidade e proporção, não se verificou. Contudo, os protestos não passaram de restritos relatórios de inspeção, pois, para a elite, formar mais ou menos, sendo atividade manual, não traria grandes prejuízos para seus descendentes que estariam estudando para atividades intelectuais e para serem dirigentes da nação e não trabalhadores.

Concluímos que o uso da expressão "aprendizes artífices" se referia, na época, a alunos que iriam aprender atividades que lhes assegurariam as funções socioeconômicas de contramestres e, principalmente, de operários. A expressão "aprendizes e artífices" passaria a modificar o sentido da época para formação iniciais simples de várias atividades mecânicas manuais, simples, ao lado da formação efetiva de artífices - contramestres e operários.

$\mathrm{Na}$ ordem sócio-hierarquizada da época, as atividades manuais estavam estamentadas: as mais importantes eram os artistas, depois os oficiais, depois os mestres e contramestres, depois os operários e, por fim, os demais, sem qualquer qualificação. Assim, ser um artífice, seja operário ou contramestre, tinha pequena valoração social e econômica. Porém, como os Liceus praticamente não formavam oficiais ou mestres, e as Escolas de Aprendizes Artífices praticamente não formavam contramestres, a distância entre as atividades manuais de um artista e de um operário era diminuída.

$\mathrm{O}$ uso adequado das expressões e seu escoramento nas concepções de uma época desvelam a natureza política e sociocultural da língua. O uso oficial desta representação induz à constatação de uma concepção de mundo e de uma prática a ser observada aos concidadãos.

Estudarmos os termos, a partir de uma surpresa pelo uso diferente do atual, mostrou-se uma ferramenta arqueológica para desnudar o valor legal e social de uma instituição escolar. Seu valor e intenção representam os desejos políticos e sociais de uma época bem como a percepção do que sejam os pobres, a natureza das diferenças sociais e os remédios paliativos, em doses adequadas para cada classe, a fim de minimizar os efeitos danosos da pobreza. 


\section{REFERÊNCIAS}

AMORIM, Fabrício da S. Variação diacrônica e ensino. Revista Tabuleiro de Letras. Salvador, v. 12, n. 3, p. 51-65, dez. 2018. Disponível em: http://www.revistas.uneb.br/ index.php/tabuleirodeletras/article/viewFile/5566/3500. Acesso em: 19 abr. 2020.

BARBARESCO, Cleber S. Saberes a ensinar aritmética na Escola de Aprendizes Artífices de Santa Catarina (1909-1937) lidos nos documentos normativos e livros didáticos. 2019. Mestrado ( Educação Científica e Tecnológica) - Universidade Federal de Santa Catarina, Florianópolis, 2019.

BIELINSKI, Alba C. O Liceu de Artes e Ofícios - sua história de 1856 a 1906. 19\&20, Rio de Janeiro, v. 4, n. 1, jan. 2009. Disponível em: http://www.dezenovevinte.net/ ensino_artistico/liceu_alba.htm. Acesso em: 12 jun. 2019.

BRASIL. Decreto $n^{\circ} 7.566$. Rio de Janeiro, 23 de setembro de 1909. Créa nas capitaes dos Estados da Escolas de Aprendizes Artífices, para o ensino profissional primario e gratuito. Rio de Janeiro, RJ: Presidência da República, 23 set. 1909. Disponível em: http:// portal.mec.gov.br/setec/arquivos/pdf3/decreto_7566_1909.pdf. Acesso em: 11 maio 2019.

BRASIL. Lei $n^{\circ} 10.097$, de 19 de dezembro de 2000. Altera dispositivos da Consolidação das Leis do Trabalho - CLT, aprovada pelo Decreto-Lei no 5.452, de 1o de maio de 1943. Diário Oficial da União: seção 1, Brasília, DF, n. 244, p. 1-175, 20 dez. 2000.

BRASIL. Ministério da Educação. Centenário da Rede Federal de educação profissional e tecnológica. Brasília, DF: Ministério da Educação, 23 set. 2009. Disponível em: http:// portal.mec.gov.br/setec/arquivos/centenario/historico_educacao_profissional.pdf. Acesso em: 11 maio 2019.

CAIRES, Vanessa G.; OLIVEIRA, Maria Auxiliadora M. Educação profissional brasileira: da Colônia ao PNE 2014-2024. Petrópolis, Rio de Janeiro: Vozes, 2016.

CARVALHO, Marcelo A. M. de. Nilo Peçanha e o sistema federal de escolas de aprendizes artífices (1909 a 1930). 2017. Tese (História Econômica) - Universidade de São Paulo, São Paulo, 2017.

CHAUÍ, Marilena. Convite à filosofia. São Paulo: Ática, 2000.

CUNHA, Celso; CINTRA, Luís F. L. Nova gramática do português contemporâneo. 7. ed. de acordo com a novo ortografia. Rio de Janeiro: Lexikon Editora Digital, 2017.

CUNHA, Luiz A. O ensino de oficios artesanais e manufatureiros no Brasil escravocrata. São Paulo: Editora UNESP; Brasília: Flacso, 2000a.

CUNHA, Luiz A. O ensino industrial-manufatureiro no Brasil. Rev. Bras. Educ., Rio de Janeiro, n. 14, p. 89-107, maio/ago. 2000b. Disponível em: http://www.scielo.br/scielo. php?script $=$ sci_arttext\&pid $=$ S 1413-24782000000200006\&lng=en\&nrm $=$ iso. Acesso em: 19 abr. 2020. 
FERREIRA, Marieta de Moraes. Nilo Peçanha. In: ABREU, Alzira Alves de et al (coord.). Dicionário histórico-biográfico da Primeira República. Rio de Janeiro: CPDOC, 2010. Disponível em: https://cpdoc.fgv.br/sites/default/files/verbetes/primeira-republica/ PEÇANHA,\%20Nilo.pdf. Acesso em: 10 maio 2019.

FERREIRA, Avelino. Nilo Peçanha: o homem, o político. Homenagem da Câmara Municipal de Campos dos Goytacazes. Campos dos Goytacazes, RJ: Câmara Municipal, 05 out. 2016. Disponível em: http://www2.camaracampos.rj.gov.br/livretonilo.pdf. Acesso em: 10 maio 2019.

FIGUEIREDO, Cândido. Novo Diccionário da Língua Portuguesa. 2. ed. Lisboa: Tavares Cardoso \& Irmão, 1913. Disponível em: http://dicionario-aberto.net/dict.pdf. Acesso em: 12 maio 2019.

FONSECA, Celso S. da. História do ensino industrial no Brasil. Rio de Janeiro: SENAIS/ DN/DPEA, 1986.

FREIRE, Paulo. Pedagogia do oprimido. 17. ed. Rio de Janeiro: Paz e Terra, 1987.

GOMES, Luiz C. G. Imagens e memórias da Escola de Aprendizes Artífices de Campos. REUNIÃO ANUAL DA ASSOCIAÇÃO NACIONAL DE PÓS-GRADUAÇÃO E PESQUISA EM EDUCAÇÃO, 27., Caxambu, 2005. Anais [...]. Caxamabu: ANPED, 2005. Disponível em: http://27reuniao.anped.org.br/gt02/p024.pdf. Acesso em: 10 maio 2019.

GOOGLE Brasil segue no topo entre os buscadores. exame., São Paulo, 13 mar. 2013. Tecnologia. Disponível em: https://exame.com/tecnologia/google-brasil-segue-no-topoentre-os-buscadores/. Acesso em: 12 maio 2019.

GUERRA, Andréia; BRAGA, Marco; REIS, José C. Uma Breve História da Ciência Moderna. v. 2. Rio de Janeiro: Jorge Zahar Editores, 2004.

KUNZE, Nádia C. O surgimento da Rede Federal de Educação Profissional nos primórdios do regime republicano. Revista brasileira da educação profissional e tecnológica, Brasília: MEC, SETEC, v. 2, n. 2, p. 8-24, nov. 2009.

LUDERITZ, João. Relatório. Apresentado ao Ministro da Agricultura, Indústria e Comércio. Rio de Janeiro: Oficinas Gráficas da Lito, Tipografia Fluminense, 1925.

MACEDO, Geisla M.; SAPUNARU Raquel A. Uma breve história da engenharia e seu ensino no Brasil e no mundo: foco Minas Gerais. REUCP, Petrópolis, v. 10, n. 1, p. 39-52, 2016.

MEDEIROS NETA, Olívia M.; NASCIMENTO, José M.; RODRIGUES, Andrea G. F. Uma escola para aprendizes artífices e o ensino profissional primário gratuito. HOLOS, [s.l.], v. 2, p. 96-104, maio 2012. Disponível em: http://www2.ifrn.edu.br/ojs/index.php/ HOLOS/article/view/919/534. Acesso em: 19 abr. 2020.

MÜLLER, Meire T. O Senai e a educação profissionalizante no Brasil. Revista HISTEDBR On-line, Campinas, n. 40, p. 189-211, dez. 2010. Disponível em: https://periodicos.sbu. unicamp.br/ojs/index.php/histedbr/article/view/8639814/7377. Acesso em: 19 abr. 2020. 
NEILPATE. Sites de busca: conheça os 10 buscadores mais usados no mundo. Blog NeilPatel, [s.l.], [2019?]. Disponível em: https://neilpatel.com/br/blog/sites-de-busca/. Acesso em: 12 maio 2019.

PRESIDENTE DA SEMANA: Episódio 6: Afonso Pena, morto no cargo, e Nilo Peçanha, o presidente mulato. [Locução de]: Rodrigo Vizeu. Convidadas Lilia Moritz Schwarcz e Mary Del Priore. São Paulo: Folha de São Paulo, 21 maio 2018. Podcast, 27 min. Disponível em: https:/www1.folha.uol.com.br/poder/2018/05/podcast-conta-historia-de-afonso-penamorto-no-cargo-e-nilo-pecanha-o-presidente-mulato.shtml?utm_source=whatsapp\&utm medium=social\&utm_campaign=compwa. Acesso em: 22 fev. 2020.

ROCHA LIMA, Carlos H. da. Subsidios para o estudo da partícula e em algumas construções da língua portuguesa. Rio de Janeiro: Botelho Editora, 2010.

SILVA, Débora de Oliveira e; RAVANELLI, Antônio. Particularidades morfossintáticas entre o adjetivo e o advérbio. In: ENCONTRO LATINO AMERICANO DE INICIAÇÃO CIENTÍFICA, 12.; ENCONTRO LATINO AMERICANO DE PÓS-GRADUAÇÃO, 8., 2008, São José dos Campos, SP. Anais eletrônicos [...]. S. José dos Campos, SP: Universidade do Vale do Paraíba, 2008. Disponível em: http://www.inicepg.univap. br/cd/INIC_2008/anais/arquivosINIC/INIC1258_02_A.pdf. Acesso em: 19 abr. 2020.

SILVA, Ricardo G. A.; ARRAES NETO, Enéas; SILVA, Napiê G. A. Educação: uma abordagem crítica. Revista Saberes, Natal, v. 1, n. 7, p. 20-33, jun. 2012.

SOARES, Manoel de J. A. As Escolas de Aprendizes Artífices e suas fontes inspiradoras. Fórum educacional. Rio de Janeiro, v. 5, n. 4, p. 69-77, out./dez. 1981.

SOARES, Manoel de J. A. As Escolas de Aprendizes Artífices - estrutura e evolução. Fórum educacional. Rio de Janeiro, v. 6, n. 2, p. 58-92, jul./set. 1982.

VARGAS, Milton. Ciência, técnica e realidade. Revista USP, n. 14, p. 96-103, São Paulo, 1992.

VARGAS, Milton (org.). História da técnica e da tecnologia no Brasil. São Paulo: Editora Unesp: Centro Estadual de Educação Tecnológica Paulo Souza, 1994.

Texto recebido em 22/02/2020.

Texto aprovado em 22/04/2020. 